\title{
Role of four Phytoseiid mite species and Acarophagous Ladybird, Stethorus gilvifrons (Mulsant) as Bioagents of the Two Spotted Spider Mite Tetranychus urticae Koch.
}

\author{
M. A. Osman ; G. M. Abou-Elella ${ }^{* \star}$ and A. A. Tawfik ${ }^{* \star \star}$ \\ "Agricultural Zoology Dept., Faulty of Agric., Mansoura Univ., Mansoura, Egypt. mesoma20@mans.edu.eg \\ "* Pests and Plant Protection Dept., National Research Center, Dokki, Cairo, Egypt \\ *** Plant Protection Research Institute, Agriculture Research Center, Dokki, Cairo, Egypt
}

(Received: June 20, 2010)

\begin{abstract}
Predaceous insects and mites are important biological control agents of the two spotted spider mite Tetranychus urticae Koch. Biology and life table parameters of Stethorus gilvifrons Mulsant, Phytoseiulus persimilis A.- H., Neoseiulus cucumeris (Oud.), Typhlodromips swirskii (A.- H.) and Euseius scutalis A.- H. fed on T. urticae immatures was studied at $28 \pm 1{ }^{\circ} \mathrm{C}$. Their female life cycle and life span averaged $17.66,5.80,4.40,6.26 \& 6.26$ days and 47.60, 19.13, 38.00, $43.20 \& 23.93$ days, respectively. During its life span, average female fed on $1647.13,343.53,353.53,345.66 \& 200.33$ with a daily rate $34.60,17.96,9.30,8.00$ and $8.37 \mathrm{~T}$. urticae immatures respectively. The net rate of natural increase $\left(r_{m}\right)$ and the finite rate of increase $\left(\mathrm{e}^{\mathrm{rm}}\right)$ of the aforementioned predators were $0.139,0.294,0.349,0.261 \& 0.229 ;$ and $1.15,1.34,1.41,1.29 \& 1.25$, respectively. These of $T$. urticae were 0.222 and 1.24 , respectively.
\end{abstract}

Key Words: Stethorus gilvifrons, Phytoseiulus persimilis, Neoseiulus cucumeris, Typhlodromips swirskii, Euseius scutalis, Tetranychus urticae, Life tables.

\section{INTRODUCTION}

The two spotted spider mite, Tetranychus urticae Koch (Acari: Tetranychidae), is a world wide pest commonly found on many agricultural crops. More than 900 species of host plants have been recorded for T. urticae (Bolland et al. 1998). Its most important predators are phytoseiid mites and coccinellid insects of the genus Stethorus (Roy et al., 2005). Phytoseiids, are generally more effective than predatory insects in controlling mites at low population levels because of lower food requirements, short life cycle, ability to survive on alternative food sources and good host-searching ability. (Huffaker et al., 1970 ; McMurtry et al., 1970 and Gerson et al., 2003). Phytoseiids have been divided in four categories according to feeding habits. Type l, consists only of Phytoseiulus spp. that are predators of heavily webbing spider mites, mostly Tetranychus spp. Type II, species feed on spider mites, but are not restricted to Tetranychus spp., feeding on other small mites as well as on pollens. Type III, phytoseiids that often prefer prey other than spider mites (because of being entangled in prey webs), such as tarsonemids and thrips. Type IV comprises genus Euseius, generalist predators that develop and reproduce successfully on pollens, but it can become entangled within spider mite webbing (McMurtry and Croft, 1997). The species most often used in greenhouses are Phytoseiulus persimilis Athias-Henriot (a type I species), Typhlodromips swirskii (A.-H.) and Neoseiulus cucumeris (Oudemans) (type III) (Gerson and Weintraub, 2010). The major impact of generalists predators, such as Euseius species, prefer low population densities of spider mites, where they may prevent the widespread colonization (James, 1990; McMurtry, 1992; McMurtry et al., 1992 and Badii et al., 2004).

Members of Stethorus have been reported as obligate predators of spider mites (Felland and Hull, 1996; Obrycki and Kring, 1998; Rott and Ponsonby, 2000 and Biddinger et al.,2009) and several species have been reported to be effective biological control agents (Gotoh et al., 2004 and Mori et al., 2005 ). They are feeding on all prey stages, having high host-finding, high dispersal potential, and longliving adults (Tanigoshi and McMurtry, 1977a, b; Roy et al., 2003). Stethorus gilvifrons Mulsant is a native beneficial coccinellid in Egypt (El-Adawy et al., and 2001 Osman, 2005), Middle East and Southern Europe Aksit et al. (2007). Therefore, the present work aims to study and evaluate the different biological aspects and food consumption of $S$. gilvifrons, $P$. persimilis, $N$. cucumeris, T. swirskii and E. scutalis (A-H.) fed on immatures of T. urticae.

\section{MATERIALS AND METHODS}

Biological studies of $S$. gilvifrons, $P$. persimilis, $N$. cucumeris, $T$. swirskii, $E$. scutalis and the prey $T$. urticae

Newly deposited 30 eggs from each predator were singly transferred to modified Huffaker cells (Sabelis, 1981; Overmeer, 1985), reared to the adult stage and observed daily until death. The cell was 
prepared by a piece of Plexiglas $(8 \times 4 \mathrm{~cm}$ and $5 \mathrm{~mm}$ of thickness) with a circular hole of $1.5 \mathrm{~cm}$ diameter in the middle. A second Plexiglas plate of the same size forms the base of the cell. On this second plate, a moistened filter paper was laid on which a piece of castor plant leaf placed upside down. A transparent coverslip closed the cell and all the pieces were held together with rubber bands. Predatory mites were reared with ample of prey that was replenished daily. Observations on development and food consumptions were recorded twice a day for the whole life span. On other hand, leaf discs of $R$. communis, one square inch, were used as a substrate for rearing newly deposited eggs of $T$. urticae. The leaf discs were placed on a wet cotton pad in Petri dishes ( $15 \mathrm{~cm}$ in diameter). at $28 \pm 1^{\circ} \mathrm{C}$ and $70 \pm 5$ $\%$ RH.. Observations on life development for both predators and prey were recorded twice a day during its life span.

\section{Statistical analysis}

Data were analysed by one way analysis of variance (ANOVA), and the means were separated using Duncan's Multiple Range Test (CoHort Software, 2004).

Life table parameters were calculated using a BASIC computer program (Abou-Setta et al. 1986) for females reared on various tested temperature degrees. Constructing a life table, using rates of agespecific (Lx), and fecundity (Mx) for each age interval $(\mathrm{x})$ was assessed. The following population growth parameters were determined: the mean generation time $(T)$, gross reproductive rate (GRR) $(=\Sigma \mathrm{Mx})$, the net reproductive increase $\left(R_{\sigma}\right)$, the intrinsic rate of increase $\left(r_{m}\right)$, and the finite rate of increase ( $(\lambda)$. The doubling time $(D T)$, Cohort Generation Time $\left(T_{c}\right)$, Capacity of increase $\left(r_{c}\right)$ and Annual rate of increase (ARI) were calculated according to (Laughlin, 1965; May, 1976; Carey, 1993).

\section{RESULTS AND DISCUSSION}

\section{Immature stages:}

Table (1) shows that larvae $S$. gilvifrons, $P$. persimilis, N. cucumieris, T. swirskii and E. scutalis hatched after $3.53,2.13,1.00,2.13$ and 1.80 days, respectively at $28 \pm 1{ }^{\circ} \mathrm{C}$. On the other hand, T. urticae female larvae hatched after 3.60 days. Femalle life cycle of $S$. gilvifrons, $P$. persimilis, $N$. cucums ris, T. swirskii and E. scutalis averaged $17.66,5.80,4.40,6.26$ and 6.26 days, respectively when fed on immatures of $T$. urticae. whereas, $T$. urticue female life cycle was 9.80 days. No significant difference between $P$. persimilis,
T. swirskii and E. scutalis females life cycle but the difference was significant between predators and T. urticae. Similar results were obtained by Mridul and Badal (2002) who noticed that $S$. gilvifrons fed on Oligonychus coffee Neither completed life cycle in 16.33 days under laboratory conditions. Also, Fiaboe et al., (2007) showed that life cycle of $S$. tridens Gordon durated 17.4 days when fed T. evansi Baker \& Pritchard at $27^{\circ} \mathrm{C}$. while, Taghizadeh et al., (2008a) stated that $S$ gilvifrons completed its life cycle after 12.49 days when fed on T. urticae at $30^{\circ} \mathrm{C}$. On the other hand, most phytoseiid species completed their life cycle at a constant temperature of $25-28{ }^{\circ} \mathrm{C}$ with in a range of 5-8 days (Fouly and El-Laithy, 1992: Osman, 2000: Popov and Kondryakov, 2008; Abou-Awad et al., 2009 and Abad-Moyano et al., 2009). Whereas, Mahgoub (2006) stated that life cycle of $N$. cucumeris feamale durated $4.4,6.6$ and 6.3 days when reared on eggs, immatures and adults of $T$. urticae respectively at $30^{\circ} \mathrm{C}$. Ali and Zaher (2007) reported that life cycle of $T$. swirskii durated 14.2 days when fed on immatures of T. urticae at $25^{\circ} \mathrm{C}$.

Developmental durations and number of eggs laid per female of $S$. gilvifrons, $P$. persimilis. $N$. cucumeris, T. swirskii, E. scutalis and T. urticae were recorded in Tables $(1 \& 3$ ). Osman (2000) stated that longevity and life span of $S$. gilvifrons were 36.46 and 56.40 days respectively when reared T. urticae on immature at $25^{\circ} \mathrm{C}$. Imani et al., (2009) showed its longevity averaged 58.00 and 45.05 when reared on $T$. turkestani and $E$ orientalis respectively. On the other hand, El-Laithy and Fouly (1992) found that adult female longevity of E. scutalis and T. swirskii durated 27.12 and 29.32 days, respectively when reared on T. urticae at $25^{\circ} \mathrm{C}$. Takahashi and Chant (1994) stated that life span of $P$. persimilis was 23 days at $26{ }^{\circ} \mathrm{C}$. Osman (2000) reported that adult female longevity and life span of E. scutalis reared on immatures of T. urticae at $26^{\circ} \mathrm{C}$ were 21.76 and 29.04 days, respectively. Also, Mahgoub (2006) stated that female adult longevity and life span of $N$. cucumeris reared on eggs, immatures and adults of T. urticae at $30{ }^{\circ} \mathrm{C}$ were $18.7,32.1$ and 36.4 days and $23.1,38.7$ and 42.7 respectively., Ali and Zaher (2007) showed that female adult longevity and life span of T. swirskii durated 53.3 and 67.5 days, when reared on immatures of $T$. urticae at $25{ }^{\circ} \mathrm{C}$. Also, Al-Shammery (2010) recorded that adult longevity and life span of E. scutalis female durated 26.4 and 34.42 days, when reared on immatures of $T$. urticae at $26{ }^{\circ} \mathrm{C}$.

Table (2) shows feeding capacity of immature 
Table (1): Comparative duration (Mean \pm S.E. in days) of female of Stethorus gilvifrons, Phytoseiulus persimilis, Neoseiulus cucumeris, Typhlodromips swirskii, Euseius scutalis and Tetranychus urticae at $28 \pm 1{ }^{0} \mathrm{C}$.

\begin{tabular}{|c|c|c|c|c|c|c|c|c|}
\hline \multirow{2}{*}{ Sp. } & \multicolumn{2}{|c|}{$\begin{array}{c}\text { Developmental } \\
\text { durations }\end{array}$} & \multirow{2}{*}{ Life cycle } & \multicolumn{4}{|c|}{ Adult stage } & \multirow{2}{*}{ Lifespan } \\
\hline & Egg & $\begin{array}{c}\text { Total } \\
\text { immatures }\end{array}$ & & $\begin{array}{c}\text { Pre- } \\
\text { oviposition }\end{array}$ & Oviposition & $\begin{array}{c}\text { Post- } \\
\text { oviposition }\end{array}$ & Longevity & \\
\hline S. gilvifrons & $3.53 \pm 0.19^{a}$ & $14.13 \pm 0.36^{a}$ & $17.66 \pm 0.39^{a}$ & $2.93 \pm 0.20^{a}$ & $20.66 \pm 1.27^{b}$ & $6.33 \pm 0.77^{h}$ & $29.60 \pm 1.91^{\circ}$ & $47.60 \pm 1.83^{a}$ \\
\hline P. persimilis & $2.13 \pm 0.09^{b}$ & $3.66 \pm 0.12^{d e}$ & $5.80 \pm 0.10^{c}$ & $1.66 \pm 0.15^{d}$ & $8.66 \pm 0.21^{d}$ & $2.86 \pm 0.33^{c}$ & $13.33 \pm$ & $\pm 0.42^{e}$ \\
\hline N. cucumeris & & $3.40 \pm 0.13^{e}$ & $4.40 \pm 0.13^{d}$ & $2.20 \pm 0.10^{b c}$ & $21.26 \pm 0.61^{a b}$ & $10.26 \pm 0.28^{a}$ & $33.60 \pm 0$ & $\pm 0.61^{c}$ \\
\hline T. swir & & $4.13 \pm 0.09^{c d}$ & $6.26 \pm 0.11^{c}$ & $2.33 \pm 0.12^{h}$ & $23.13 \pm 0.70^{\alpha}$ & $11.40 \pm 0.63^{a}$ & 36.80 & $=0.95^{b}$ \\
\hline E. scutalis & $1.80 \pm 0$. & $4.46 \pm 0.23^{c}$ & & $1.80 \pm 0.14^{\text {cd }}$ & & $3.20 \pm 0.14^{c}$ & 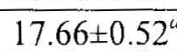 & $=0.62^{d}$ \\
\hline T. urticae & $3.60 \pm 0.13^{a}$ & $6.20 \pm 0.14^{h}$ & $9.80 \pm 0.17^{h}$ & $1.86 \pm 0.19^{\text {hcd }}$ & $10.26 \pm 0.45^{d}$ & $1.93 \pm 0.20^{c}$ & $14.06 \pm 0.39$ & $23.86+0.46^{d}$ \\
\hline
\end{tabular}

Means in each column having different letters are significantly different $(\mathrm{P}<0.05)$

Table (2): Feeding capacity (Mean \pm S.E. in days) of immature stages and adult female of Stethorus gilvifrons, Phytoseiulus persimilis, Neoseiulus cucumeris, Typhlodromips swirskii and Euseius scutalis fed on immatures of Tetranychus urticae at $28 \pm 1{ }^{\circ} \mathrm{C}$.

\begin{tabular}{lcccccc}
\hline \multicolumn{1}{c}{ Sp. } & Total immatures & Daily rate & Longevity & Daily rate & Lifespan & Daily rate \\
\hline S. gilvifrons & $84.73 \pm 2.82 a$ & $5.99 \pm 0.34 b$ & $1562.40 \pm 51.89 a$ & $52.78 \pm 1.59 a$ & $1647.13 \pm 128.54 a$ & $34.60 \pm 2.03 a$ \\
\hline P. persimilis & $25.46 \pm 0.51 b$ & $6.95 \pm 0.30 a$ & $318.06 \pm 4.88 b$ & $23.86 \pm 1.19 b$ & $343.53 \pm 5.14 b$ & $17.96 \pm 0.92 b$ \\
\hline N. cucumeris & $11.86 \pm 0.30 c$ & $3.48 \pm 0.16 c$ & $341.66 \pm 14.75 b$ & $10.17 \pm 0.67 c$ & $353.53 \pm 14.68 b$ & $9.30 \pm 0.42 c$ \\
\hline T. swirskii & $9.93 \pm 0.39 c$ & $2.40 \pm 0.16 d$ & $335.73 \pm 10.63 b$ & $9.12 \pm 0.41 c$ & $345.66 \pm 10.58 b$ & $8.00 \pm 0.18 c$ \\
\hline E. scutalis & $8.20 \pm 0.29 c$ & $1.83 \pm 0.15 d$ & $192.13 \pm 7.39 c$ & $10.88 \pm 0.49 c$ & $200.33 \pm 7.29 b$ & $8.37 \pm 0.25 c$ \\
\hline
\end{tabular}

Means in each column having different letters are significantly different $(\mathrm{P}<0.05)$.

Table (3): Life table parameters of Stethorus gilvifrons, Phytoseiulus persimilis, Neoseiulus cucumeris, Typhlodromips swirskii, Euseius scutalis and Tetranychus urticae at $28 \pm 1{ }^{\circ} \mathrm{C}$.

\begin{tabular}{lcccccccccc}
\hline \multicolumn{1}{c}{ Sp. } & Mean Total Fecundity & $\mathrm{R}_{0}$ & $\mathrm{~T}$ & $\mathrm{r}_{\mathrm{m}}$ & $\mathrm{e}^{\mathrm{m}}$ & $\mathrm{GRR}$ & $\mathrm{DT}$ & $\mathrm{T}_{\mathrm{c}}$ & $\mathrm{r}_{\mathrm{c}}$ & ARI \\
\hline S. gilvifrons & $91.80 \pm 3.06 \mathrm{a}$ & 56.36 & 28.83 & 0.139 & 1.15 & 64.16 & 4.96 & 31.31 & 0.129 & $1.41 \times 10^{22}$ \\
\hline P. persimilis & $35.60 \pm 1.56 \mathrm{~d}$ & 22.02 & 10.51 & 0.294 & 1.34 & 24.02 & 2.35 & 11.17 & 0.277 & $5.66 \times 10^{46}$ \\
\hline N. cucumeris & $46.86 \pm 1.08 \mathrm{c}$ & 27.78 & 9.51 & 0.349 & 1.41 & 35.33 & 1.97 & 14.31 & 0.232 & $3.77 \times 10^{55}$ \\
\hline T. swirskii & $45.06 \pm 0.96 \mathrm{c}$ & 26.70 & 12.58 & 0.261 & 1.29 & 32.28 & 2.64 & 16.62 & 0.197 & $3.58 \times 10^{41}$ \\
\hline E. scutalis & $29.73 \pm 0.85 \mathrm{e}$ & 16.84 & 12.28 & 0.229 & 1.25 & 18.84 & 3.01 & 14.35 & 0.196 & $2.39 \times 10^{36}$ \\
\hline T. urticae & $64.80 \pm 5.40 \mathrm{~b}$ & 36.98 & 16.19 & 0.222 & 1.24 & 42.23 & 3.11 & 17.20 & 0.209 & $2.13 \times 10^{35}$ \\
\hline
\end{tabular}

$\mathrm{R}_{0}$ : Net reproductive rate, $T$ : Mean generation time, $r_{m}$ : Intrinsic rate of increase, $e^{\mathrm{rm}}$ : Finite rate of increase, GRR Gross reproductive rate, DT: Doubling time, $T_{c}$ : Cohort generation time, $r_{c}$ : Capacity of increase, ARI: Annual rate of increase

stages and adult females of $S$. gilvifrons, $P$. persimilis, N. cucumeris, T. swirskii and E. scutalis . Osman (2005) reported that S. gilvifrons female consumed 2384.53 with a daily rate 42.27 immatures of T. urticae at $25^{\circ} \mathrm{C}$. while, Fiaboe et al., (2007) stated that $S$. tridens Gordon consumed 67.8 nymphs of T. evansi Baker \& Pritchard daily in the oviposition period. Also, Perumalsamy et al., (2010) showed that $S$. gilvifions female consumed 205.0 eggs, 92.2 larvae, 81.8 nymphs or 52.4 adult mites per day when reared on $O$. coffecae. Ali and Zaher (2007) reported that $T$. swirskii female mite consumed 120.70 and 131.00 immatures of $T$. urticae during its longevity and life span $w$ ith a daily rate of 2.30 and 1.70 at $25^{\circ} \mathrm{C}$. while, Kazak (2008) indicated that $P$. persimilis female consumed a daily rate 15.41 of $T$. cinnabarinus protonymphs at $30^{\circ} \mathrm{C}$. Also, Abd el Wahed (2007) noticed that female of N. cucumeris consumed 78.8 and 95 moving stages during its life span.

\section{Life table parameters:}

Life table parameters of the predatory lady bird beetle $S$ gilvifrons and phytoseiid mites, are presented in Table (3). Fig. 1 clearly indicated that the survival curves of $S$ gilvifions, $P$. persimilis, N. cucumeris, T. swirskii and E. scutalis fed on $T$. urticae immatures at $28{ }^{\circ} \mathrm{C}$ followed a type I 

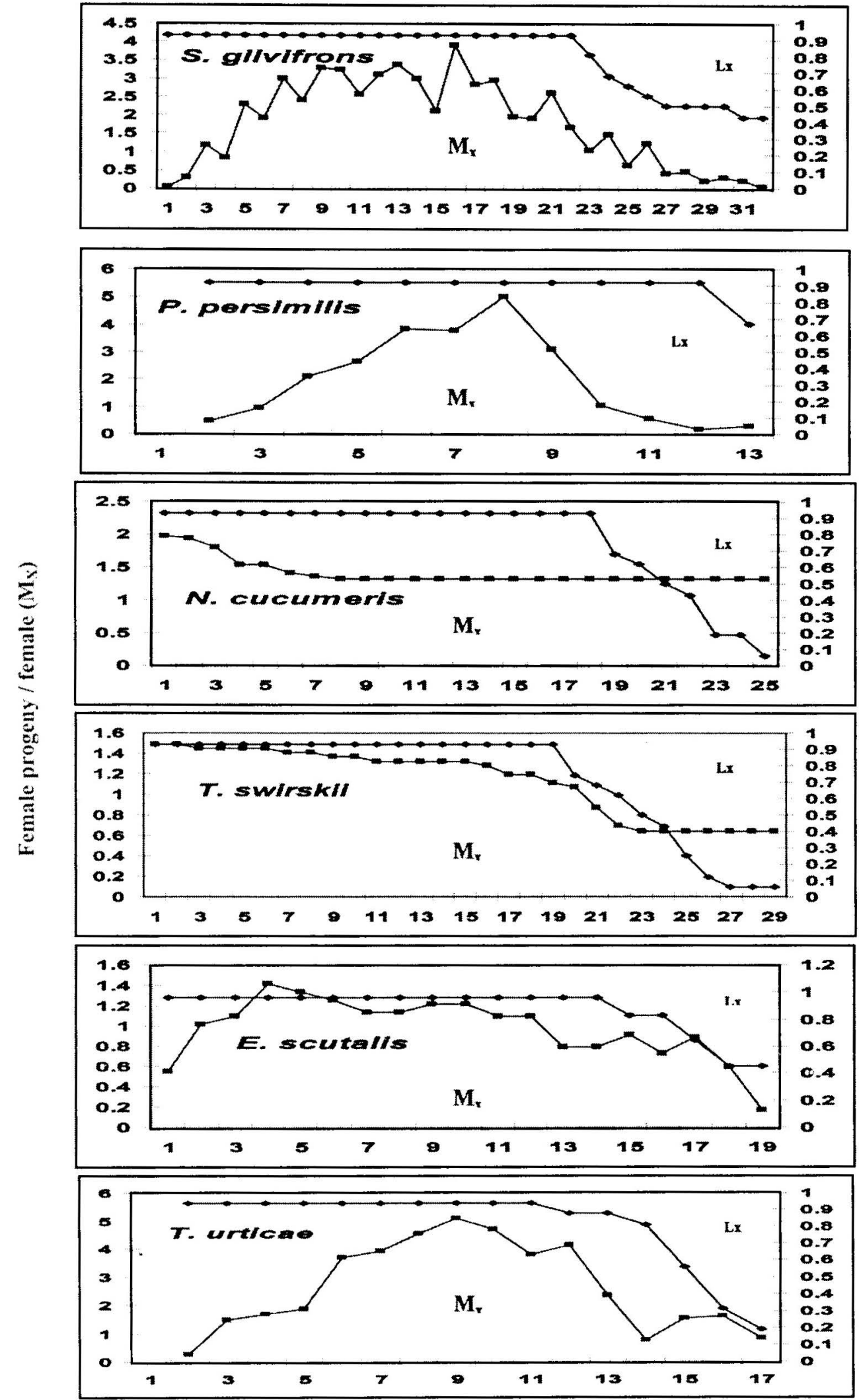

Mite age (days)

Fig.(1): Comparison between Age - specific fecundity $\left(\mathrm{M}_{\mathrm{x}}\right)$, survivorship $\left(\mathrm{L}_{\mathrm{x}}\right)$ of $S$, gilvifrons, $P$. persimilis,

N. cuctmeris. T. swirskii, E. scutalis and their prey T. urticae at $28 \pm 1^{\circ} \mathrm{C}$. 

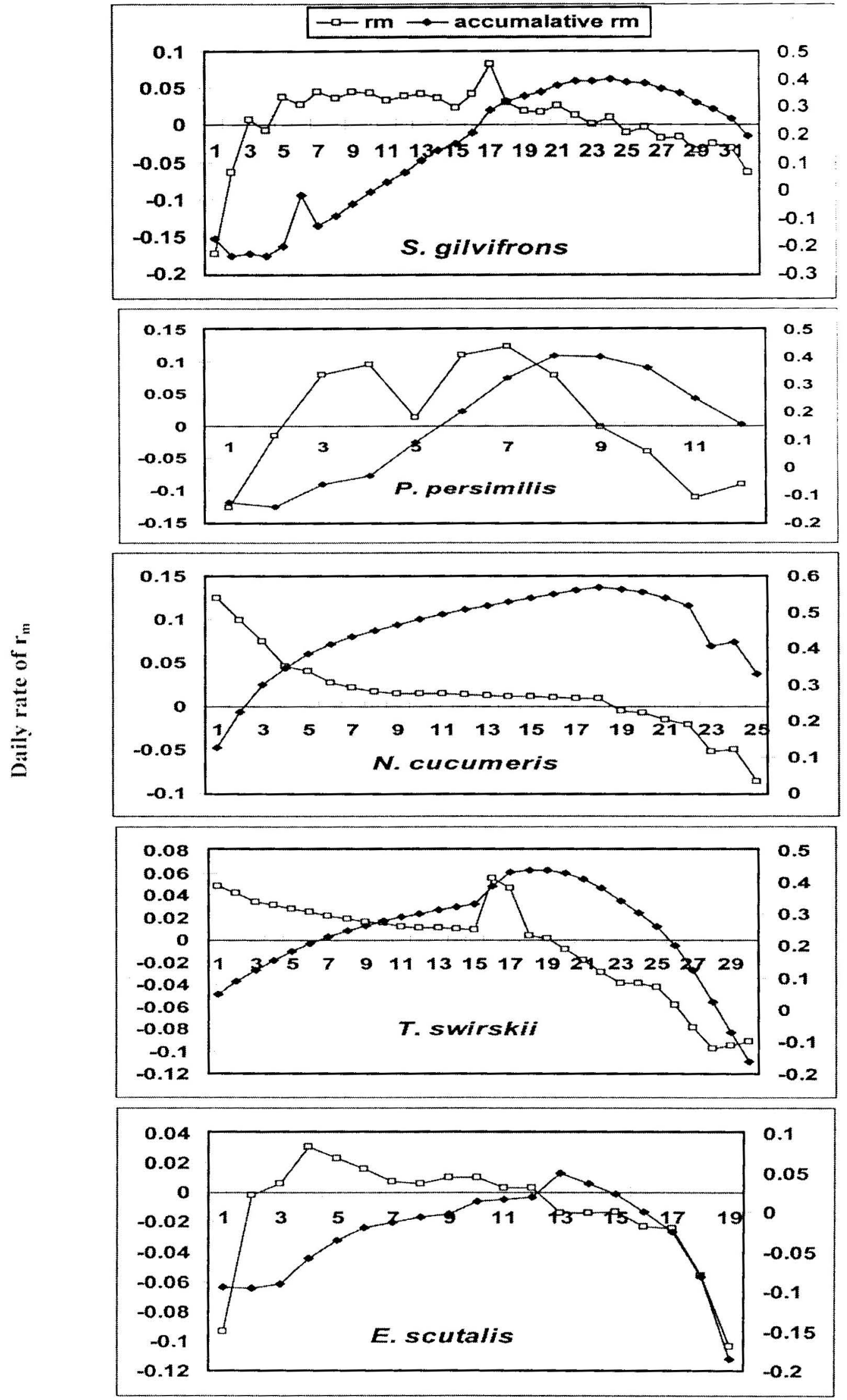

Female's age at time of oviposition $(x)$

Fig. (2): Accumulative contribution to the $\mathrm{r}_{\mathrm{m}}$ of $S$ gilvifrons, P. persimilis, $N$. cucumbris. $T$....... scutalis at $28 \pm 1$ "C timales fecundity in successive age classes. 
pattern in which most eggs developed to maturity and death occurred gradually over an extended ovipositional period (Fig. 1). These results agree with that of (Fouly and El-Laithy, 1992; Abou-setta et al.. 1997; Fouly, 1997; Osman, 2000; Osman, 2005; Al-Shammery, 2010).

The net reproductive rate $\left(\mathrm{R}_{0}\right)$ was the highest for $S$. gilvifrons, 56.36 and the lowest for E. scutalis, 16.84. Also, the mean generation time $(\mathrm{T})$ averaged 28.83. 10.51, 9.51, 12.58 and 12.28 for $S$. gilvifrons, $P$. persimilis, $N$. cucumeris, $T$. swirskii and E. scutalis respectively. The present results revealed that $S$. gilvifrons, $P$. persimilis, $N$. cucumeris, T. swirskii and E. scutalis could multiply 56.36, $22.02,27.78,26.70$ and 16.84 times in a generation time $28.83 \quad 10.51 \quad 9.51 \quad 12.58$ and 12.28 for the aforementioned predators respectively., whereas, T. urticae could multiply 36.98 times in a generation time 16.19 .

Similar data obtained by Taghizadeh et al. (2008b) who reported that $S$. gilvifrons reared on T. urticae recorded $R_{0}$ and $T 47.54$ and 20.17 at $30{ }^{\circ} \mathrm{C}$. Imani et al. (2009) showed that $\mathrm{R}_{0}$ and $\mathrm{T}$ were 97.6. 154.08 and 26.76, 22.83 when $S$. gilvifrons reared on T. turkestani and E. orientalis respectively at $30^{\circ} \mathrm{C}$. El-Laithy and Fouly (1992) found that $\mathrm{R}_{0}$ of $E$. scutalis and T. swirskii were 17.22 and 22.97 when reared on T. urticae. Osman (2000) showed that $R_{0}$ and $T$ of $E$. scutalis was 16.03 and 28.63 , respectively when reared on immatures of T. urticae at $25^{\circ} \mathrm{C}$. Ali and Zaher (2007) recorded that $\mathrm{R}_{0}$ and $T$ of $T$. swirskii when reared on immatures and eggs of $T$. urticae were $7.40,25.92$ and 6.92,25.52, respectively. Also, AlShammery (2010) reported that $R_{0}$ and $T$ of E. scutalis were 26.373 and 14.88 when reared on T. urticae at $26^{\circ} \mathrm{C}$.

However, the intrinsic rate of natural increase $\left(r_{m}\right)$ is a useful parameter for predicting the population growth potential of an animal under environmental conditions, as it reflects an overall effect on development, reproduction and survival (Southwood and Handerson 2000). Data in table (3) showed that $r_{m}$ values were $0.139,0.294,0.349$, 0.261 and 0.229 individuales / female / day when $S$. gilvifrons, $P$. persimilis, $N$. cucumeris, $T$. swirskii and $E$. scutalis reared on immatures of $T$. urticae, respectively, while, for $T$. urticae was 0.222 individuales / female / day. $\mathrm{e}^{\mathrm{mm}}$ ranged between 1.15 and 1.41 for predators and 1.24 for $T$. urticae. Osman, 2005 recorded that $\mathrm{r}_{\mathrm{m}}$ and $\mathrm{e}^{\mathrm{rm}}$ of $S$. gilvifrons were 0.12 and 1.13 when reared on immatures of T. urticae at $25^{\circ} \mathrm{C}$. Also, Taghizadeh et al. (2008b) showed that $\mathrm{r}_{\mathrm{m}}$ and $\mathrm{e}^{\mathrm{rm}}$ of $S$. gilvifrons were 0.19 and 1.21 when reared on immatures of $T$. urticae at $30{ }^{\circ} \mathrm{C}$. Imani et al. (2009) reported that $\mathrm{r}_{\mathrm{m}}$ and $\mathrm{e}^{\mathrm{rm}}$ were $0.17,1.186$ and $0.22,1.24$ when $S$. gilvifrons reared on $T$. turkestani and $E$. orientalis respectively at $30{ }^{\circ} \mathrm{C}$. The biotic potential $\left(\mathrm{r}_{\mathrm{m}}\right)$ of the main phytoseiid species constitutes $0.18-0.334$; maximal values at optimal environmental conditions of P. persimilis are 0.219-0.334 (Laing, 1968; Popov and Kondryakov 2008). However, estimates of $r_{m}$ are difficult to compare between studies, because of genetic variation, differences in rearing methods and other environmental conditions, and variable assumptions entering these estimations (Roy et al., 2003). Additionally, the intrinsic rate of increase $\left(r_{m 1}\right)$ depending on female age, showed a decline fluctuating curve for $S$. gilvifrons, $P$. persimilis, N. cucumeris, T. swirskii and E. scutalis (Fig. 2). Correspondingly, accumulative $\mathrm{r}_{\mathrm{m}}$ curve for $S$. gilvifrons, $P$. persimilis, $N$. cucumeris, $T$. swirskii and E. scutalis followed a similar trend and declined after 17, 8, 18, 19, 16 days after emergence. This result has to be considered in future bio-control programs i.e., female of $S$. gilvifrons, $N$. cucumeris, T. swirskii and E. scutalis should be periodically released in three weeks interval and 10 days for P. persimilis.

Theoretically, a predator that has a population growth rate $\left(r_{m}\right)$ equal or greater than its prey could be able to regulate the population of its prey (Sabelis, 1992). In biological control practice, $r_{m}$ value is increasingly used as means for selecting promising biocontrol candidates on the basis of its reproductive potential and to predict the outcome of pest-natural enemy interactions (Jervis and Copland, 1996). In the present study the $r_{m}$ value of $S$. gilvifrons was lower than that of its prey T. uricae. A similar situation was observed by McMurtry et al., (1974) on Stethorus picipes Casey $\left(\mathrm{r}_{\mathrm{m}}=0.12\right.$ day- 1 at $\left.25^{\circ} \mathrm{C}\right)$ preying on Oligonychus punicae (Hirst) on avocados. Also, Muraleedharan et al., (2005) recorded that the $\mathrm{r}_{\mathrm{m}}$ value of $S$. gilvifrons was lower than that of its prey $O$. coffeae. The explanation could be that under highly favourable conditions, high predation rates by Stethorus spp. could eliminate prey more rapidly than they can reproduce (Roy et al., 2003 and Perumalsamy et al., 2010).

On the other hand, the doubling time (DT) of S. gilvifrons, $P$. persimilis, $N$. cucumeris, $T$. swirskii and E. scutalis recorded 4.96, 2.35, 1.97, 2.64 and 3.01 days when reared on immatures of T. urticae. Also, gross reproductive rate (GRR) was 64.16, $24.02,35.33,32.28$ and $18.84 \mathrm{eggs} /$ female. 
Perumalsamy et al., (2010) recorded that DT and GRR of $S$. gilvifrons were 10.5 days and $82.3 \mathrm{eggs} /$ female when reared on $O$. coffeae at $25^{\circ} \mathrm{C}$.

In the present study, the cohort generation time $\left(\mathrm{T}_{\mathrm{c}}\right)$ of $S$. gilvifrons, $P$. persimilis, $N$. cucumeris, $T$. swirskii and E. scutalis were $31.31,11.17,14.31$, 16.62 and 14.35 , while capacity of increase $\left(r_{c}\right)$ recorded $0.129,0.277,0.232,0.197$ and 0.196 . Also, annual rate of increase (ARI) of $S$. gilvifrons, $P$. persimilis, $N$. cucumeris, $T$. swirskii and E. scutalis was $1.41 \times 10^{22}, 5.66 \times 10^{46}, 3.77 \times 10^{55}, 3.58 \times$ $10^{41}, 2.39 \times 10^{36}$. On the other hand, the cohort generation time $\left(\mathrm{T}_{\mathrm{c}}\right)$, capacity of increase $\left(\mathrm{r}_{\mathrm{c}}\right)$ and annual rate of increase (ARI) of T. urticae was $17.20,0.209$ and $2.13 \times 10^{35}$. Hoque et al. (2008) reported that $\left(\mathrm{T}_{\mathrm{c}}\right)$ for $P$. Persimilis was 10.754 , 13.747 and 22.252 in summer, autumn and winter seasons. Also, $\left(r_{c}\right)$ was 0.17470 .1715 and 0.0960 in the same seasons. $\left(\mathrm{T}_{\mathrm{c}}\right)$ and $\left(\mathrm{r}_{\mathrm{c}}\right)$ of T.urticae were $13.057,15.934$ and 28.972 and $0.1676,0.1735$ and 0.0544 in summer, autumn and winter seasons, respectively.

The afro-mentioned results revealed that lady bug $S$. gilvifrons belonging to the genus Stethorus is obligate predator of tetranychid mites. Therefore, it is highly recommended to play an important role for supressing $T$. urticae population in open fields and in greenhouses. Also, $P$. persimilis, N. cucumeris, $T$. swirskii and E. scutalis could play effective role against the aforementioned pest.

\section{REFERENCES}

Abad-Moyano, R.; Pina, T.; Ferragut, F. and Urbaneja, A., 2009. Comparative life-history traits of three phytoseiid mites associated with Tetranychus urticae (Acari: Tetranychidae) colonies in clementine orchards in eastern Spain: implications for biological control. Exp. Appl. Acarol. 47:121-132

Abd el wahed, N. M., 2007. Biological studies of predacious mite, Neoseiulus cucumeris (Oudemans) when feeding on citrus red mite, Panonychus citri (McGregor). Egypt.J. Agric. Res. 85: $1253-1258$.

Abou-Awad, B. A.; Metwally, A. M. and Al-Azzazy, M.M., 2009. Typhlodromips swirskii (Acari: Phytoseiidae): A predator of eriophyid and Tetranychid mango mites in Egypt. Acarines, 3: 59-64.

Abou-Setta M.M. and Childers C.C., 1986. Life 48: a BASIC computer program to calculate life table parameters for an insect or mite species.
Fla. Entomol. 69: 690-697.

Aksit, T.; Cakmak, I. and Ozer, G., 2007. Effect of temperature and photoperiod on development and Fecundity of an Acarophagous Ladybird Beetle, Stethorus gilvifrons. Phytoparasitica 35:357-366

Ali, F. S. and Zaher, M. A., 2007. Effect of food and temperature on the biology of Typhlodrompis swirskii (Athias- Henriot) (Acari : Phytoseiidae), ACARINES, 1: 17 - 22.

Al-Shammery, K. A., 2010. Different biological aspects of the predaceous mite Euseius scutalis (Acari: Gamasida: Phytoseiidae) and the effects due to feeding on three tetranychid mite species in Hail, Saudi Arabia. Asian Journal of Biological Sciences. 3 : 77- 84.

Badii, M. H., Ortiz, E. H. , Flores, A. E. and Landeros, J., 2004. Prey stage preference and functional response of Euseins hibisci to Tetranychus urticae (Acari: Phytoseiidae, Tetranychidae). Exp. Appl. Acarol. 34:263-273.

Biddinger, D. J.; Weber, D. C. and Hull, L. A., 2009. Coccinellidae as predators of mites: Stethorini in biological control. Biol. Control, 51: 268-283.

Birch, L. C., 1948. The intrinsic rate of natural increase of an insect population. J.Anim.Ecol., 17: $15-26$.

Bolland, H. R.; Gutierrez, J. and Flechtmann C. H. W., 1998. World catalogue of the spider mite family (Acari: Tetranychidae). Koninklijke Brill NV, Leiden, The Netherlands.

Carey, J. R., 1993. Applied demography for biologists with special emphasis on insects. Oxford University Press, NewYork.

El-Adawy, A. M.; Abdel-Gawad, N. M. and El-Sharkawy, T. A., 2001. Castor bean, Ricinus communis, a promising source of mite's predators. Egyptian Journal of Agricultural Research. 79: 1, 149-160.

El-Laithy, A. Y. and Fouly, A. H., 1992. Life table parameters of the two phytoseiid predators Amblyseius scutalis (Athia-Henriot) and swirskii A. H. (Acari, Phytoseiidae) in Egypt. J. Applied Entomol., 113:8-12.

Felland, C.M. and Hull, L.A., 1996. Cver vintering of Stethorus punctum punctum (Coleoptera: Coccinellidae) in apple orchards ground cover. Environ. Entomol. 25, 972-976.

Fiaboe, K.K.M.; Gondim Jr, M.G.C.; de Moraes, G. J.; Ogol, C. K. P. O and Knapp, M., 2007. Bionomics of the acarophagous ladybird beetle Stethorus tridens fed Tetranychus evansi. J. Appl. Entomol. 131(5), 355-361

Fouly, A. H., 1997. Effect of prey mites and pollen on the biology and life tables of Proprioseipsis asetus (Chant) (Acari: Phytoseiidae). J. Appl. 
Ent. 121: 8, 435- 439.

Fouly, A. H. and El- Laithy, A. Y., 1992. Immature stages and life histrory of the predatory mite species Amblyseius barkeri (Hughes) (Acarina: Gamasida, Phytoseiidae). Deutsche Entomol, Zeitschrift, 39: 427-435.

Gerson, U.; Smiley R.L. and Ochoa, R.. 2003. Mites (Acari) for Pest Control. Blackwell Science, Oxford, UK.

Gerson, U. and Weintraub, P. G., 2010. Mites for the control of pests in protected cultivation. Pest Manag. Sci. 63: 658-676.

Gotoh, T.; Nozawa, M. and Yamaguchi, K., 2004. Prey consumption and functional response of three acarophagous species to eggs of the twospotted spider mite in the laboratory. Appl. Entomol. Zool. 38, 7-14.

Hoque, M. F.; Islam, W. and Khalequzzaman, M., 2008. Life tables of two spotted spider mite Tetranychus urticae koch (Acari: Tetranychidae) and its predator Phytoseiulus persimilis Athias-Henriot (Acari: Phytoseiidae). J. Bio. Sci. 16: $1-10$

Huffaker, C.B. ; Van de Vrie, M. and McMurtry, J. A., 1970. Ecology of tetranychid mites and their natural enemies: a review. II. Tetranychid populations and their possible control by predators: an evaluation. Hilgardia 40: 391-458.

Imani, Z.; Shishehbor, P. and Sohrabi, F., 2009. The effect of Telranychus turkestani and Eutetranychus orientalis (Acari: Tetranychidae) on the development and reproduction of Stethorus gilvifions (Coleoptera: Coccinellidae). J. of Asia-Pacific Entom., 12: 213-216.

James, D.G., 1990. Biological control of Tetranychus urticae (Koch) (Acari: Tetranychidae) in New South Wales peach orchards: the role of Amblyseius victoriensis (Acari: Phytoseiidae). Aust. J. Zool., 37:645-655.

Jervis, M.A. and Copland, M. J.W., 1996. The life cycle. In: Jervis M, Kidd B (eds) Insect natural enemies: practical approaches to their study and evaluation. Chapman and Hall, London, 63-161.

Kazak, C.. 2008. The development, predation, and reproduction of Phytoseinlus persimilis AthiasHenriot (Acari: Phytoseiidae) from Hatay Fed Tetranychus cinnabarinus Boisduval (Acari: Tetranychidae) larvae and protonymphs at different temperatures. Turk J. Zool., 32:407-413.

Laing, J. E., 1968. Life History and Life Table of Phyloseiulus persimilis Athias-Henriot. Acarologia 10: 578-588.

Laughlin. R., 1965 Capacity for increase: a useful population statistic. J. of Anim. Ecology, 34:77-91.
Mahgoub, M. H., 2006. Studies on certain predatory mites attaking arthropod pests infesting cucumber in plastic house. Ph. D. Thesis. Fac. Agric., cairo Univ., Egypt.

May, R. M., 1976. Estimating r: a pedagogical note. American Naturalist, 110, 496-9.

McMurtry, J. A., 1992. Dynamics and potential impact of mgeneralist' phytoseiids in agroecosystems and possibilities for establishment of exotic species. Exp. Appl. Acarol., 14: 371-382.

McMurtry, J. A. and Croft, B.A., 1997. Life styles of phytoseiid mites and their roles in biological control. Ann. Rev. Entomol.42:291-321.

McMurtry, J. A.; Huffaker, C. B. and Van de Vrie, M., 1970. Ecology of tetranychid mites and their natural enemies: a review. I. Tetranychid enemies: their biological characters and the impact of spray practices. Hilgardia 40, 331-390.

McMurtry, J.A.; Morse, J.G. and Johnson, H.G., 1992. Studies of the impact of Euseius species (Acari: Phytoseiidae) on citrus mites using predator exclusion and predator release experiments. Exp. Appl. Acarol., 15: 233-248.

McMurtry, J. A.; Scriven, G. T. and Malone, R. S., 1974 Factors affecting oviposition of Stethorus picipes (Coleoptera: Cocinellidae) with special reference to photoperiod. Environ Entomol $3: 123-127$.

Mori, K.; Nozawa, M., Arai, K. and Gotoh, T., 2005. Life-history traits of the acarophagous lady beetle, Stethorus japonicus at three constant temperatures. BioControl, 50: 35--51.

Mridul, S. and Badal, B., 2002. Biology and feeding potential of Stethorus gilvifrons Mulsant (Coccinellidae: Coleoptera) on tea red spider mite, Oligonychus coffeae Neitner.Shashpa. 9(1): 23-26.

Muraleedharan, N., Sudarmani, D. N. P. and Selvasundaram, R., 2005. Bioecology and management of the red spider mite infesting tea in south India. In: Proceedings of International symposium on Innovation in tea science and sustainable development in tea industry. China Tea Science Society, Hangzhou, China. 756-766.

Obrycki, J.J. and Kring, T.J., 1998. Predaceous Coccinellidae in biological control. Annu. Rev. Entomol. 43: 295-321.

Osman, M. A., 2000. Feasibilty of using some predaceous mites in biological control. M. Sc. Thesis, Fac. Agric., Mansoura Univ., Egypt.

Osman, M. A., 2005. Biological and ecological studies on certain predatory insects and mites associated with phytophagous mites and feasibilityof using it in biological control. Ph. D. 
Thesis, Fac. Agric., Mansoura Univ., Egypt.

Overmeer, W. P. J., 1985. Rearing and handling. In: Helle, W., Sabelis, M.W. (Eds.), Spider Mites: Their biology, natural enemies and control. World Crop Pests. Elsevier

Perumalsamy, K.; Selvasundaram, R.; Roobakkumar, A.; Vattakandy Jasin Rahman, V. J. and Muraleedharan, N., 2010. Life table and predatory efficiency of Stethorus gilvifrons (Coleoptera: Coccinellidae), an important predator of the red spider mite, Oligonychus coffeae (Acari: Tetranychidae), infesting tea. Exp. Appl. Acarol., 50:141-150.

Popov, S. Ya. and Kondryakov, A. V., 2008. Reproductive tables of Predatory Phytoseiid Mites (Phytoseiulus persimilis, Galendromus occidentalis, and Neoseiulus cucumeris). Entom. Rev., 88: 658-665.

Rott, A.S. and Ponsonby, D.J.. 2000. The effect of temperature, relative humidity and host plant on the behaviour of Stethorus punctillum as a predator of the two-spotted spider mite, Tetranychus urticae. BioControl, 45:155-164.

Roy, M., Brodeur, J. and Cloutier, C., 2003. Effect of temperature on intrinsic rates of natural increase $\left(r_{m}\right)$ of a coccinellid and its spider mite prey. BioControl, 48: 57-72.

Roy, M. , Brodeur, J. and Cloutier C., 2005. Seasonal activity of the spider mite predators Stethorus punctillum (Coleoptera: Coccinellidae) and Neoseiulus fallacis (Acarina: Phytoseiidae) in raspberry, two predators of Tetranychus mcdanieli (Acarina: Tetranychidae). Biol. Control, 34: 47-57.

Sabelis, M.W., 1981. Biological control of twospotted spider mites using phytoseiid predators. Part I: modelling the predator-prey interaction at the individual level. Agricultural Research Reports, Pudoc, Wageningen, p. 242.

Sabelis, M. W., 1992. Predatory arthropods. In: Crawley MJ (ed) Natural enemies. The population biology of predators, parasites and disease. Blackwell, Oxford, 225-264.

Southwood, R. and Handerson, P. A., 2000. Ecological Methods, Third Edition. Blackwell publishing. 592pp.

Takahashi, F. and Chant, D.A., 1994. Adaptive strategies in the genus Phytoseiulus Evans (Acari: Phytoseiidae).II. Survivorship and reproduction. Int. J. Acarol. 20: 87-97.

Taghizadeh, R., Fathipour, Y. and Kamali, K., 2008a. Temperature-dependent development of acarophagous ladybird, Stethorus gilvifrons (Mulsant) (Coleoptera: Coccinellidae).J. AsiaPac. Entomol.,. 11:145-148.

Taghizadeh, R., Fathipour, Y. and Kamali, K., 2008b. Influence of temperature on life-table parameters of Stethorus gilvifions Mulsant (Coleoptera: Coccinellidae) fed on Tetranychus urticae Koch. J. Appl. Entomol. 132, 638-645.

Tanigoshi, L. K. and McMurtry JA, 1977a. The dynamics of predation of Stethorus picipes (Coleoptera: Coccinellidae) and Typhlodromus floridanus on the prey Oligonychus punicae (Acarina: Phytoseiidae, Tetranychidae). I. Comparative life history and life table studies. Hilgardia, 45: 237-261.

Tanigoshi, L.K. and McMurtry, J. A., 1977b. The dynamics of predation of Stethorus picipes (Coleoptera: Coccinellidae) and Typhlodromus floridanus on the prey Oligonychus punicae (Acarina: Phytoseiidae, Tetranychidae). II. Effect of initial prey-predator ratios and prey distribution. Hilgardia, 45: 262-288. 